\title{
RELACJONOWANIE KRYZYSU PRZEZ MEDIA USA W LATACH 2007-2009 JAKO PRZYKŁAD ZARZAZDZANIA INFORMACJĄ PODCZAS SYTUACJI KRYZYSOWYCH
}

\author{
Abstract \\ MEDIA COVERAGE DURING THE ECONOMIC CRISIS IN 2007-2009 \\ AS AN EXAMPLE OF INFORMATION MANAGEMENT DURING CRISIS \\ SITUATIONS
}

Crisis situations require quick decisions which are to reduce as much as possible the risk of losses for a given organization. In the case of media organizations, reactions to a crisis should be bilateral. In addition to their own internal decisions, media are supposed to report on crisis to the public. The author of the considerations wonders media coverage has an impact on the course of crisis. Based on an example of economic crisis in the USA in 2007-2009 were considered the effects that media reports or their lack can bring for the economic situation.

Key words: crisis management, information management, media coverage, economic crisis

\section{Wstęp}

Jak pisał Robert G. Picard, zarządzanie mediami można określić jako proces, w którym dualne dobro oferowane przez media jest poddawane określonym działaniom ${ }^{1}$. Zawartość mediów, a więc także informacja będąca najbardziej wartościowym towarem na rynku medialnym, będzie obejmowana przez tę definicję. Zarządzać można zasobami ludzkimi, finansowymi, rzeczowymi i właśnie informacjami.

\footnotetext{
1 R.G. Picard, Media Economics: Concepts and Issues, SAGE Publications, London 1989.
} 
Media, odkąd zaczęly być traktowane również jako przedsiębiorstwa nakierowane na zysk i element systemu gospodarczego, mają do spełnienia dwie funkcje: komercyjną oraz misję społecznej. W przypadku sytuacji kryzysowych ich misją wobec społeczeństwa jest informowanie opinii publicznej o postępujących zmianach i ważnych wydarzeniach z objętej kryzysem części życia społecznego.

Jeżeli uznać za Andrzejem K. Koźmińskim, że „zarządzanie jest swego rodzaju wędrówką przez chaos" ${ }^{\prime 2}$, to w przypadku zarządzania w sytuacjach kryzysowych można określić to jako nad wyraz utrudnione zadanie, które musi zostać dokładnie przeanalizowane i rozplanowane. Rozplanowane w taki sposób, aby było to opłacalne. Czy jednak pod presją czasu w sytuacjach kryzysowych media, tworząc i przekazując informacje, nie kierują się właśnie ową opłacalnością i interesem komercyjnym, a ich misja wobec społeczeństwa schodzi na drugi plan?

Amerykański system medialny jest zdominowany przez media prywatne i od początku swojej działalności miał charakter komercyjny. W gestii tychże organizacji leży przede wszystkim chęć osiągnięcia zysku, a to niekoniecznie musi współbrzmieć z kwestią misyjności. Celem niniejszego tekstu jest zobrazowanie cech charakterystycznych amerykańskich przekazów medialnych podczas postępującej sytuacji kryzysowej w sferze gospodarczej w latach 2007-2009, a także stworzenie pola do dyskusji na temat tego, czy podczas kryzysu realizowanie misji społecznej jest zadaniem mediów komercyjnych.

\section{Kryzys}

Kryzys - z greckiego krizis oznaczającego „rozróżnienie”, „decyzję” - to punkt zwrotny, sytuacja decyzyjna. W zarządzaniu za kryzys uznaje się stan rozwoju zagrażający podstawowym funkcjom organizacji, zagrażający jej misji. Podobnie rzecz ma się w obrębie komunikacji: kryzys to każda sytuacja odbiegająca od normalnego funkcjonowania firmy czy instytucji, to sytuacja, w której występują gwałtowne i nieprzewidywalne wydarzenia, skutkujące niekontrolowanymi reakcjami ${ }^{3}$.

Nie ma jednoznacznej definicji kryzysu, która rozgraniczałaby dokładnie problem i sytuację kryzysową. Kryzys cechują jednak zawsze trzy elementy:

- zagrożenie dla organizacji;

- element zaskoczenia;

- krótki okres decyzyjny.

Kryzysy mogą przybierać różne formy, być powodowane przez różne czynniki, nie zawsze zależne od człowieka, jednak w kontekście funkcjonowania organizacji,

2 B. Nierenberg, Publiczne przedsiębiorstwo medialne. Determinanty, systemy, modele, Wydawnictwo Uniwersytetu Jagiellońskiego, Kraków 2007, s. 96.

3 M. Czaplicka, Zarządzanie kryzysem w social media, Onepress, Gliwice 2014, s. 9. 
także tych zajmujących się komunikowaniem, działania ludzkie mają największy wpływ na kreowanie różnego rodzaju kryzysów.

Otto Lerbinger ${ }^{4}$ wyróżnia 10 rodzajów kryzysów:

\section{Katastrofy naturalne}

Są to wszystkie wydarzenia, które dzieją się z przyczyn niezależnych od człowieka, a więc np. trzęsienia ziemi, tornada czy powodzie.

2. Kryzysy technologiczne

Wydarzenia, w których winna jest technologia lub nauka, ale także człowiek nieumiejętnie korzystający z techniki.

\section{Konfrontacja}

Sytuacje, w których ludzie stanowią pewną siłę konfrontującą, np. firmę. Bojkoty są świetnym przykładem tego typu kryzysów.

4. Wrogość

Kryzys wywołany przez agresywne działania przeciwnika lub konkurencji.

5. Groźba ujawnienia tajnych danych, niewygodnych informacji

Kryzys związany z przeciekiem danych wrażliwych z organizacji, który może być spowodowany działaniami szpiegowskimi w danej firmie.

6. Organizacja

Ten kryzys wiąże się z błędami związanymi z organizacją pracy, z firmą, z wyznawanymi przez pracowników wartościami itp. Lerbinger wyróżnił tutaj trzy rodzaje tego kryzysu: kryzys wypaczonych wartości zarządzania (kiedy krótkoterminowe zyski przysłaniają inne wartości), kryzys oszustwa (wykorzystanie oszustwa w celu uzyskania czegoś) i kryzys nierzetelności zarządzania. Wszędzie tam, gdzie są zachłanni pracownicy, nieetyczne zachowanie oraz źle podjęte decyzje, istnieje zagrożenie kryzysu organizacyjnego.

7. Przemoc w miejscu pracy

Mobbing oraz inne formy wykorzystywania.

\section{Pogłoski}

Pomówienia oraz wszystkie plotki, które mogą zaszkodzić wizerunkowi marki.

9. Ataki terrorystyczne i katastrofy spowodowane przez człowieka Wszelkiego typu działania, które zostały spowodowane przez człowieka w sposób umyślny.

10. Niezadowolony klient

Zdarzenia mające związek z firmą lub oferowaną przez nią usługą, która została oceniona przez klientów w sposób negatywny.

Relacjonowanie kryzysu ekonomicznego przez media można sklasyfikować jako kryzys związany z organizacją. Według Lerbingera to problem złej organizacji, który może wynikać także z wykorzystania oszustwa w celu osiągnięcia zysku.

${ }^{4}$ O. Lerbinger, The Crisis Manager: Facing Risk and Responsibility, Erlbaum, Mahwah 1997. 
Według Chrisa Pearsona i Judith Clair kryzys organizacyjny to mało prawdopodobna sytuacja o silnym oddziaływaniu, która postrzegana jest przez udziałowców jako zagrażająca równowadze organizacji, a także jest subiektywnie doświadczana przez poszczególne jednostki jako zagrożenie osobiste i społeczne ${ }^{5}$. Przez opisane w kolejnych częściach studium przypadku będzie można się zastanowić, czy rzeczywiście to zjawisko, a raczej jego relacjonowanie na poziomie mediów masowych, ma wpływ na równowagę organizacji.

Nieprzewidywalność, działanie pod presją czasu, nasilenie częstotliwości występowania niekorzystnych zdarzeń podczas kryzysu wprowadza konieczność podejmowania natychmiastowych działań zarówno wewnątrz organizacji, jak i na zewnątrz. W przypadku organizacji medialnych wystąpienie kryzysu powinno charakteryzować się przecież dłuższym okresem przeznaczonym na podejmowanie decyzji ze względu na pełnioną przez nie funkcję watchdoga. Kryzys zaskakuje wszystkich, ale czy media także, skoro to one są odpowiedzialne za nieustanne monitorowanie wydarzeń, również w sferze gospodarczej? Konieczność błyskawicznego działania jest wymagana $\mathrm{z}$ jednej strony przez zarządzających organizacjami, z drugiej zaś w przypadku mediów postrzegana jest też jako szybkość reakcji w relacjonowania przebiegu sytuacji kryzysowej. Podczas wystąpienia takiego załamania ludzie jeszcze bardziej pożądają informacji. Próbują dowiedzieć się, co dokładnie się wydarzyło, czym to skutkuje oraz co może wydarzyć się później. Media masowe, opierając się na szybkości reakcji, często zatracają swoją dokładność w prezentowaniu przekazów. Ze względu na prawdziwy zalew informacji i natłok deadlineów prawdopodobieństwo pojawienia się niesprawdzonych i nieprawdziwych informacji wzrasta.

\section{Zarządzanie kryzysem (crisis management)}

Zarządzanie kryzysowe to proces, w którym organizacja musi zmierzyć się z zagrożeniem wypływającym $z$ danego wydarzenia i mogącym zaszkodzić tej organizacji, jej członkom lub społeczeństwu jako ogółowi ${ }^{6}$.

Zarządzanie sytuacją kryzysową dzieli się na kilka etapów:

1. Planowanie. W tej części przygotowuje się materiały, odpowiednie procedury, analizuje się najbardziej prawdopodobne scenariusze oraz monitoruje:

- możliwe sytuacje;

- ciągłość biznesową;

- architekturę informacji.

${ }^{5}$ Ch. Pearson, J. Clair, Reframing Crisis Management, „Academy of Management Review” 1998, t. 23, nr 1, s. 59-76.

${ }^{6}$ J. Bundy, M. Pfarrer, C. Short, W. Coombs, Crises and Crisis Management: Integration, Interpretation, and Research Development, „Journal of Management” 2016, t. 43, nr 6. 
3. Rozpoznanie kryzysu.

4. Wybranie i dostosowanie strategii wyjścia z kryzysu.

5. Działanie postkryzysowe.

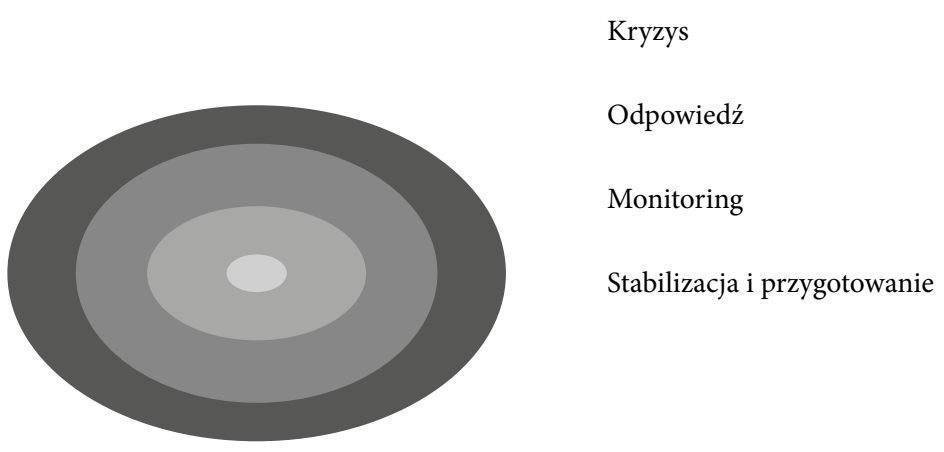

Rys. 1. Schemat narzędzi kryzysowych

Źródło: M. Czaplicka, Zarzadzanie kryzysem w social media, dz. cyt., s. 33.

"Gdy USA kicha, świat się przeziębia” - to XX-wieczne powiedzenie nigdy nie było bardziej prawdziwe niż podczas kryzysu mającego swoje apogeum w 2008 roku po ogłoszeniu bankructwa przez Lehman Brothers. W dzisiejszym świecie pełnym zależności finansowych skutki załamania na amerykańskim rynku nieruchomości, które wywołały później krach firm finansowych oraz wstrząsy na Wall Street niespotykane od lat 30 . XX wieku' ${ }^{8}$, rozprzestrzeniły się w ciągu miesięcy również na rynki całego świata. Według jednego z medioznawców, J. Tunstalla: „The media are American” - media są amerykańskie. Przez proces postępującej globalizacji to, co sprawdza się w jednym kraju, często jest przenoszone na poziom innych państw. Globalizacja w większości sektorów przybiera formę amerykanizacji czy, idąc dalej, makdonaldyzacji. Czy zatem w przypadku mediów i sposobu zarządzania nimi ten trend jest podobny? Możemy zauważyć, że strategie spółek medialnych, reklamowych, które odniosły wielki sukces za oceanem, są potem wprowadzane np. na rynkach poszczególnych krajów europejskich. A przecież należy zaznaczyć, że każdy rynek jest inny i rządzą nim cechy oraz upodobania charakterystyczne dla danego społeczeństwa. W związku z tym sposób zarządzania, także informacją, podczas relacjonowania powyższych sytuacji powinien być odrębny i specyficzny dla danego systemu medialnego i społeczeństwa.

7 D. Keating, Kryzys finansowy 2008 dla opornych, tłum. K. Kowalczyk, http://www.cafebabel. $\mathrm{pl} /$ polityka/artykul/kryzys-finansowy-2008-dla-opornych.html (dostęp: 31.10.2017).

${ }^{8}$ N. Roubini, S. Mihm, Ekonomia kryzysu, tłum. R. Mitoraj, Wolters Kluwer, Warszawa 2011, s. 20. 
Kiedyś spółki prasowe, medialne nie były notowane na giełdzie. Wraz z komercjalizacją mediów elektronicznych to się zmieniło. Pociągnęło to za sobą zbliżenie się systemu medialnego do świata handlu. Potwierdzającym to przykładem może być fakt, że w Polsce mediom publicznym nadano formę spółek prawa handlowego, które z natury nastawione są na zysk ${ }^{9}$. Organizacje medialne zaczęły odczuwać konsekwencje obecności swoich akcji na giełdach światowych i wahania ich notowań. W przypadku amerykańskich mediów odbyło się to najszybciej. Ze względu na ich dominujący charakter komercyjny najsprawniej przystosowały się do środowiska pełnego transakcji i maklerów.

Wśród czterech sfer nacisku na media podanych przez Denisa McQuaila znajduje się sfera ekonomiczna, do której zaklasyfikowane są: agencje prasowe i informacyjne, konkurenci, reklamodawcy, właściciele i związki zawodowe ${ }^{10}$. Wydarzenia takie jak kryzys finansowy również są jednym z elementów owej sfery. Stwierdzić zatem można, że media jako integralna część poszczególnych gospodarek narodowych oraz globalnego systemu komunikowania również wpływają na zaistniałe sytuacje ekonomiczne oraz je odczuwają. A do wpływania stosują zasoby, które według Petera F. Druckera zdominują XXI wiek - informacje.

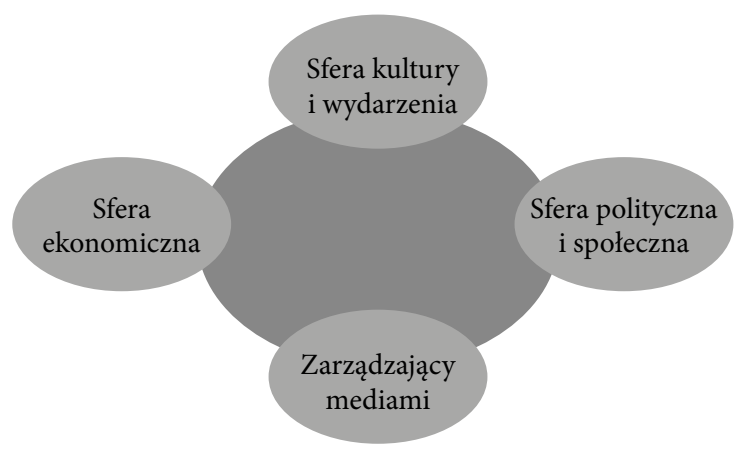

Publiczność

Rys. 2. Sfery nacisku na organizacje medialne

Na podstawie: D. McQuail, McQuail's Mass Communication Theory, SAGE Publications, London 2000, s. 250 .

Należy również zaznaczyć, że na tak obszerny zakres, jaki został objęty przez konsekwencje kryzysu ekonomicznego od 2008 roku, miały wpływ różne procesy. Jednym $\mathrm{z}$ nich jest niewątpliwie proces globalizacji, który spowodował, że kryzys

9 B. Nierenberg, Zarządzanie mediami. Ujęcie systemowe, Wydawnictwo Uniwersytetu Jagiellońskiego, Kraków 2011, s. 229.

10 D. McQuail, McQuail's Mass Communication Theory, SAGE Publications, London 2000, s. 250. 
nie zatrzymał się jedynie na jednej sferze, jednym rynku, jednym kontynencie. $\mathrm{W}$ aspekcie medialnym takim procesem może być natomiast zjawisko postępującej cyfryzacji. Lata przypadające na wystąpienie kryzysu finansowego były jednocześnie jednym z najbardziej dynamicznych etapów, jeśli chodzi o rozwój technologii cyfrowych w środkach masowego przekazu. Zwłaszcza w Stanach Zjednoczonych, gdzie od lat 90. ubiegłego wieku istniał narzucony na media publiczne przez Federal Communications Commission obowiązek cyfryzacji ${ }^{11}$. Oczywiście dotyczyło to tylko sfery mediów publicznych, jednak większa część systemu medialnego USA, czyli media komercyjne, również przeszła rewolucję digitalizacyjną, z którą wiązało się uzyskanie dużo wyższej jakości przekazu. A na rynku pełnym konkurencji oraz wymagającego audytorium nie można było odrzucić innowacji i postępu technologicznego, aby nie pozostać w tyle. I żeby nie utracić swojej dotychczasowej pozycji na rynku oraz zwiększać, a przynajmniej utrzymać swoje wpływy z reklam. Media muszą nieustannie się rozwijać. Chociażby z tego powodu, żeby cały czas być atrakcyjne zarówno dla reklamodawców, jak i odbiorców.

Dlatego jedną z najprężniej rozwijających się sfer są media społecznościowe. Stały się one platformą, za pomocą której dosłownie każdy może tworzyć informacje. Dla mediów tradycyjnych jest to jednocześnie pomocne, jak i stwarza nowe problemy, także w sytuacjach kryzysowych. Przepływ informacji stał się dużo łatwiejszy i każdy może podzielić się swoją opinią na dany temat. Sprawia to, że prasa, radio i telewizja nie są już jedynymi kanałami opiniotwórczymi, a wypowiedzi zwykłych użytkowników często wyrażają więcej, niż dane organizacje by tego chciały. Jeśli wydarzy się coś niespodziewanego, jak na przykład kryzys finansowy, to pierwsze informacje są przekazywane właśnie za pośrednictwem nowych mediów, między innymi mediów społecznościowych. Tworzy to również konieczność konwergencji mediów i nieograniczania się do jednego kanału przekazu. Dlatego też media tradycyjne kreują swoje profile na tych portalach, aby wciąż być postrzegane jako atrakcyjne i wiarygodne źródło informacji. 65\% firm z listy Fortune 500 posiada aktywne konto na Twitterze ${ }^{12}$. Potwierdza to dzisiejszą rangę mediów społecznościowych, które są respektowane także przez największe przedsiębiorstwa jako jeden z najlepszych kanałów komunikacji z klientami. Tworzy to możliwości, jakich dotąd jeszcze nie było. Zarówno pod względem targetowania reklam pod określone grono odbiorców, jak i monitorowania wydarzeń, napięć społecznych etc.

${ }^{11}$ B. Nierenberg, Publiczne przedsiębiorstwo medialne, dz. cyt., s. 99.

12 M. Czaplicka, Zarzadzanie kryzysem..., dz. cyt., s. 43. 


\section{Relacjonowanie sytuacji kryzysowych przez media jako element zarzą- dzania informacją}

Kryzys opisywany w mediach może występować na trzech różnych poziomach:

- na poziomie makro, gdzie znajdują się polityczne regulacje, gospodarki narodowe, całe społeczeństwa etc.;

- na poziomie mezo, który dotyka organizacji i skutków dla ich koniunktury;

- na poziomie mikro, opisującym złe zarządzanie przez poszczególne jednostki.

Skoro zatem mamy do czynienia ze zglobalizowanymi mass mediami, to kwestią istotną jest to, czy skupiają się one także na najniższych poziomach, opisując zjawiska z punktu widzenia jednostek, czy ograniczają się do deskrypcji na poziomie globalnym.

John M. Lavine i Daniel B. Wackman zidentyfikowali pięć charakterystycznych cech, które wyróżniają media spośród wszystkich innych przemysłów:

1. Media dostarczają „łatwo psujących się" produktów.

2. Media zatrudniają wysoce kreatywnych pracowników.

3. Media mają odrębną strukturę organizacyjną.

4. Media odgrywają społecznie istotną rolę (oddziałują na świadomość odbiorców, mogą być narzędziem wpływu etc.).

5. Zacierają się różnice pomiędzy tradycyjnymi mediami ${ }^{13}$.

Kierując się tokiem myślenia Lavine’a i Wackmana, dochodzimy także do oferty mediów na rynku dóbr i usług medialnych. Media odgrywają istotną rolę, ponieważ oddziałują na świadomość odbiorców przez oferowanie określonej usługi lub dobra medialnego, ale także umożliwianie reklamodawcom dostępu do odbiorców, gdyż są kanałem przekaźnikowym reklam ze względu na zdolność skupiania na sobie uwagi audytorium. Jest to wyznacznik dualnej natury mediów, która została określona przez Roberta G. Picarda. Media mają podwójną naturę także w aspekcie opiniotwórczości. Z jednej strony są platformą komunikacyjną dla społeczeństwa oraz politycznych i ekonomicznych aktorów. $Z$ drugiej zaś są autonomicznym komunikatorem, który wpływa na społeczeństwo jako kreator tychże opinii ${ }^{14}$.

${ }_{13}$ J.M. Lavine, D.B. Wackman, Managing Media Organizations: Effective Leadership of the Media, Longman, New York 1988, s. 7.

${ }^{14}$ Ch. Suter, M. Herkenrath (red.), World Society in the Global Economic Crisis, LIT Verlag, Zurich 2012, s. 287. 


\section{Relacjonowanie kryzysu ekonomicznego przez media amerykańskie w latach 2007-2009 - studium przypadku}

Bardzo niewiele empirycznych badań poświęconych zostało szczegółowemu opisowi kryzysu, który rozpoczął się w 2007 roku i jego przebiegu w danych spółkach medialnych. Większość $\mathrm{z}$ nich, jak chociażby wzięta w rozważaniach pod uwagę analiza zrealizowana przez Pew Research Center, zawierała wniosek, że jednym z czynników, które przyczyniły się do poszerzenia opisywanego kryzysu, były właśnie relacje mediów masowych. Nie dostrzegły one w porę zagrożenia i nie przygotowały odpowiedniego ostrzeżenia dla społeczeństwa przed nadchodzącymi konsekwencjami. A relacjonowanie kryzysu już post factum było zbyt mało aktualne i przekazy medialne były zdecydowanie spóźnione.

Zastanowić się wszakże należy, dlaczego media były ze swoimi relacjami spóźnione. Jeśli mamy do czynienia $\mathrm{z}$ nagłym, ważnym zdarzeniem, to informacje na ten temat są przez społeczeństwo pożądane, atrakcyjne, a więc przynoszące zysk. Współczesny system informacyjny działa na zasadzie breaking news - jeśli nagle zdarzy się coś bardzo istotnego, to natychmiast zaczyna się o tym mówić w mediach. Czy jednak kryzys gospodarczy, spowodowany poprzedzającymi go załamaniami na rynku nieruchomości, rynku kredytowym oraz w strukturze bankowej, można określić jako sytuację tak nagłą, że media, będące „ośrodkiem monitorującym" wszystkie strefy życia społecznego, nie mogły się do niego odpowiednio przygotować? Mogłyby one wówczas stworzyć przekazy medialne będące niejako ostrzeżeniem dla społeczeństwa przed nadchodzącym zagrożeniem. W jaki sposób media miały uzyskać pewność co do możliwych rozmiarów niebezpieczeństwa i jak miałyby przewidzieć jego przebieg? Małgorzata Zaleska podkreśla, że „wszelkie informacje o ewentualnych problemach instytucji finansowych powinny być podawane w sposób wyważony"15. Dlatego też możliwe jest, że strategia relacjonowania wydarzeń będących następstwami kryzysu gospodarczego przyjęta przez media w Stanach Zjednoczonych była ostrożna i zachowawcza $\mathrm{z}$ tego względu, że emocjonalny przekaz mógłby jeszcze bardziej zagrozić określonym instytucjom finansowym. Przekazywanie danych będących dla poszczególnych organizacji danymi wrażliwymi jest $\mathrm{z}$ tego powodu regulowane. W Stanach Zjednoczonych dostęp do raportów bankowych jest utrudniony i dziennikarze, którzy chcą uzyskać wgląd w określone dokumenty, muszą zwracać się z pisemną prośbą do władz o ich udostępnienie.

W związku z tym przeprowadzone zostały badania relacji medialnych. Anali$\mathrm{za}^{16} \mathrm{z}$ lat 2007-2009 skupiała się na zawartości mediów, w tym przypadku prasy, i jej

${ }_{15}$ M. Zaleska, Przyczyny i skutki kryzysu w USA, http://www.bankier.pl/wiadomosc/Przyczyny-i-skutki-kryzysu-w-USA-1739652.html (dostęp: 21.09.2018).

${ }_{16}$ M. Schranz, M. Eisengger, The Financial Crisis and the Media: An Analysis of Newspapers in the United Kingdom, the United States and Switzerland between 2007 and 2009, [w:] Ch. Suter, M. Herkenrath (red.), World Society..., dz. cyt., s. 287-298. 
związku z tematem trwającego kryzysu. Do opisu zjawiska posłużono się następującymi zmiennymi:

1) stopień intensywności oraz koncentracji na relacjonowaniu kryzysu. Formułowanie artykułów oraz używane zwroty związane z tematyką kryzysu (np. kryzys ekonomiczny, globalny kryzys); rozróżnienie w opisie na poziomy mikro-, mezo-, makroekonomiczne;

2) wskazywanie przyczyn kryzysów (ramy diagnostyczne); określanie genezy powstałej sytuacji oraz winnych w poszczególnych sferach (np. politycznej, ekonomicznej);

3) wskazywanie możliwych rozwiązań kryzysu (ramy prognostyczne); kreowanie opinii publicznej i próba znalezienia możliwych wyjść z sytuacji kryzysowej.

Badania wykazały, że najbardziej wpływowy dziennik w Stanach Zjednoczonych - za jaki uznano „The New York Times” - zamieścił na przestrzeni dwóch lat od rozpoczęcia kryzysu ponad 826 poświęconych mu artykułów na pierwszych stronach ${ }^{17}$. Obraz kryzysu w mediach zaczął pojawiać się relatywnie późno. Początkowa faza kryzysu, spowodowana zwiększeniem dostępności subprime mortgage, czyli kredytów dla osób z niewystarczającymi możliwościami finansowymi, nie była ukazywana w mediach jako problem, który może wiązać się z dalece idącymi konsekwencjami, aż do połowy roku 2007.

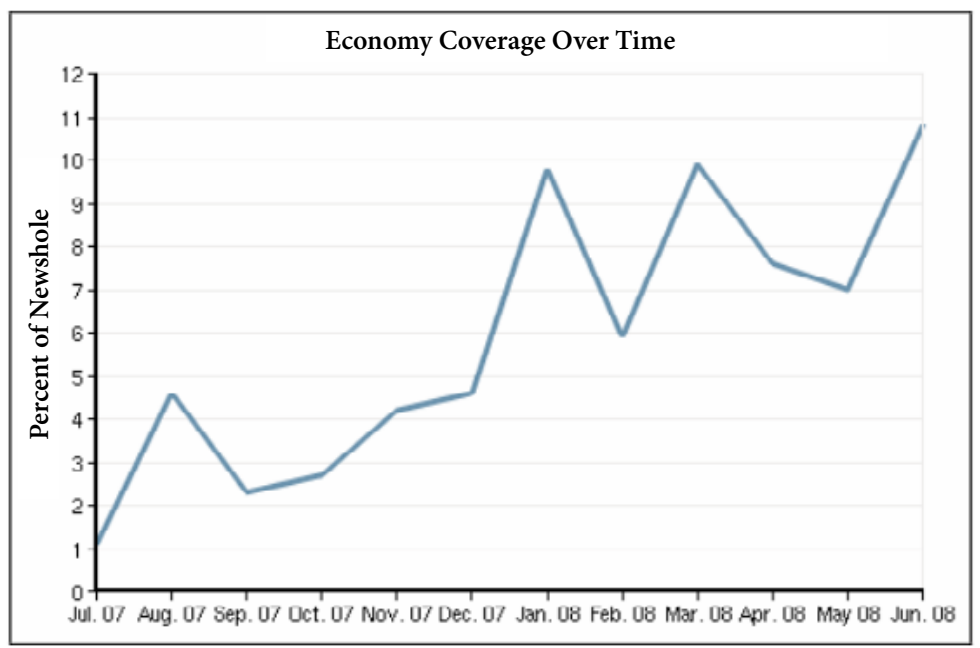

Rys. 3. Wykres przedstawiający zmieniający się poziom relacjonowania zjawisk ekonomicznych przez media w USA

Źródło: The Changing Narrative: How the News Media Have Covered the Slowing Economy, http://www. journalism.org/files/legacy/Economy\%20report.pdf (dostęp: 2.11.2017).

${ }_{17}$ Analizie poddano również dwa najbardziej wpływowe dzienniki z innych krajów: szwajcarski „Neue Zürcher Zeitung” oraz brytyjski „The Guardian”. 
W tym okresie było widać już pewne zmiany, które ciągnęły za sobą skutki w systemie bankowym i które później musiał regulować FED (bank centralny Stanów Zjednoczonych). Poziom wskazywania pogarszającej się sytuacji ekonomicznej jako głównego problemu społecznego wzrósł z 5\% w połowie 2007 roku do $26 \%$ w roku $2009^{18}$. Można stwierdzić zatem, że funkcja „sejsmograficzna” mediów nie zadziałała tutaj w sposób umożliwiający wcześniejsze zaalarmowanie opinii publicznej, a co za tym idzie - zwiększenie świadomości odbiorców w sferze, która ich dotyczyła. Trudno wszak jednoznacznie stwierdzić, że wcześniejsza reakcja i ostrzeżenie ze strony mediów uchroniłyby system finansowy od skutków kryzysu lub chociażby je zminimalizowały. Choć w tym przypadku takie wcześniejsze sygnały ostrzegawcze miały miejsce. Już w 2005 roku media sporadycznie zaznaczały, że istnieje duże ryzyko związane ze strukturą kredytów bez pokrycia. Niestety nie przyczyniło się to do uprzedniej refleksji środowiska kredytodawców i kredytobiorców.

Czy w tej sytuacji można zatem określić media jako „nocnego stróża” państwa? Czy nie tworząc odpowiednich przekazów medialnych, mających ukierunkować opinię publiczną na konkretny problem, jakim w tym przypadku był postępujący kryzys finansowy, nie tracą one swojej funkcji watchdoga? Organizacje medialne nastawione są na zysk jak każde przedsiębiorstwo, aczkolwiek media publiczne są dużo bardziej skomplikowanym tworem, ponieważ regulują je normy prawne ustanowione przez państwo. Należałoby w tym miejscu ponownie zauważyć, że wszystkie media mają do spełnienia dwie funkcje ${ }^{19}$ :

- misję społeczną,

- funkcję komercyjną.

Co zatem z pierwszą funkcją? Aby dokonać rzetelnej analizy tego zjawiska, należałoby się odnieść do specyfiki amerykańskiego systemu medialnego. Jak wspomniano wyżej, obowiązek realizacji misji wobec społeczeństwa mają wszystkie media. Warto jednak dostrzec różnicę pomiędzy misyjnością mediów publicznych a prywatnych. Te pierwsze podlegają władzy państwowej, a także społeczeństwu. Inaczej sprawa ma się w przypadku mediów prywatnych, które kierowane są przez konkretnych właścicieli i to oni są decydentami w tychże mediach. Nie dostają poleceń z góry wskazujących, co mają publikować, a czego nie. A to właśnie media prywatne dominują w amerykańskiej strukturze medialnej, natomiast rola nadawców publicznych jest raczej znikoma.

W kolejnej pracy badawczej ${ }^{20}$ opisującej media covering kryzysu ekonomicznego w Stanach Zjednoczonych także skupiono się na analizie zawartości przekazów medialnych i ich adekwatności. Podkreślono tutaj po raz kolejny, że media podczas

${ }_{18}$ Na podstawie badań wszystkich trzech powyższych tytułów prasowych.

19 B. Nierenberg, Zarzadzanie mediami..., dz. cyt., s. 81.

${ }^{20}$ M. Dickinson, Where Were the Media in the Financial Crisis of 2008, and Have We Seen This Trend Before?, http://digitalcommons.bryant.edu/cgi/viewcontent.cgi?article=1006\&context=honors_communication (dostęp: 21.09.2018). 
relacjonowania tej kryzysowej dla społeczeństwa amerykańskiego sytuacji zawiodły. Komunikaty były jednoznacznie spóźnione, a poszczególne zagadnienia przekazywane fragmentarycznie.

Warto podkreślić tutaj pracę reporterów podczas zdawania relacji do swoich redakcji. Czy będąc jednymi z gate keeperów w procesie tworzenia informacji, nie selekcjonowali ich w taki sposób, aby uniknąć wcześniejszych załamań w sferze finansowej? Czy nie chcieli w ten sposób uniknąć bycia postrzeganymi jako ktoś, kto próbuje zaostrzać zaistniałą sytuację? Rzeczą wartą podkreślenia jest, że unikali oni tworzenia relacji we wcześniejszym okresie problemów na rynku nieruchomości i rynku kredytowym, ponieważ bali się, że mogą w ten sposób jeszcze pogłębić nadchodzący kryzys. Mieli również przypuszczenia co do tego, że mogą przyczynić się zarówno do strat finansowych określonych instytucji w tym sektorze, jak i utraty zaufania do nich jako instytucji o niskim poziomie zaufania społecznego. Także jeśli chodzi o deskryptywność zjawiska kryzysu, media były bardziej ostrożne. Używały mniej agresywnych zwrotów. Zamiast pisać, że jakiś bank „jest bliski bankructwa”, łatwiej i bezpieczniej było użyć sformułowania, że dany bank „notuje duże spadki”. Dziennikarze sami przyznawali, że jeśli wiadomo było, iż działo się coś naprawdę dramatycznego, to przez odpowiedni dobór słów starali się temu wydarzeniu nadać niższą rangę, aby jednoznacznie nie określać i nie definiować sytuacji jako kryzysowej. Unikali również wyrażeń dotyczących ewentualnej paniki. Przez zbyt częste podnoszenie danych aspektów kryzysu media mogły niejako kreować atmosferę strachu wśród społeczeństwa. Zwłaszcza ludziom mieszkającym w Ameryce taka sytuacja mogła kojarzyć się z kolejnym Wielkim Kryzysem, jak ten z 1929 roku, którego skutki, pomimo upływu lat, są pamiętane do dziś jako przestroga z przeszłości.

Skoro dziennikarze, którzy otrzymywali polecenia od swoich przełożonych o minimalizowaniu rzetelnego opisu na temat stanu sektora finansowego i realizowali te zalecenia, to czy w ten sposób nie łamali niepisanej umowy ze społeczeństwem, nie przekazując ludziom informacji oddających stan rzeczy w stu procentach?

Rzecz ta nie miała związku z posiadaniem przez media sprawdzonej u źródeł wiedzy. Określić to można jako brak zainteresowania ze strony mediów masowych i nieopłacalność takich tematów. W głównym nurcie bardziej wartościowe dla większości organizacji medialnych było tworzenie przekazów medialnych zawierających informacje, kto na przykład wygrał ostatnią edycję popularnego reality show czy datę premiery najnowszego modelu telefonu komórkowego znanego producenta, ponieważ te tematy były popularniejsze wśród masowej publiczności. Media jako przedsiębiorstwa nakierowane na zysk w ekonomicznym rozrachunku po prostu zdecydowały, że owe informacje będą towarem bardziej atrakcyjnym. Popyt na informacje o sytuacji na rynku ekonomicznym jest relatywnie niewielki i dotyczy raczej określonej grupy społecznej (ludzi interesujących się lub zajmujących się tym na co dzień, np. ekonomistów), której poświęcone są specjalne programy czy rubryki branżowe, nieśledzone przez szerokie grono odbiorców. Wiązało 
się to jednak z zawężeniem informacji na temat wcześniejszego załamania na rynku nieruchomości oraz w sektorze kredytowym i spowodowało brak adekwatnego ostrzeżenia dla społeczeństwa. Z tego też powodu wielu konsumentów, będących jednocześnie odbiorcami mediów, dowiedziało się o rzeczywistych skutkach kryzysu dopiero po odczuciu ich na własnej skórze.

Za głównych winowajców kryzysu i jego skutków uznano na samym początku, w pierwszej połowie 2007 roku, właścicieli nieruchomości i osoby biorące subprime mortgage, czyli kredyty bez pokrycia. Wraz z rozwojem kryzysowej sytuacji ta tendencja stopniowo się zmieniała. W 2008 roku na czele owego rankingu były wskazywane banki i instytucje z sektora finansowego. Od początku 2009 roku niechlubnym liderem wskazywanym przez opisane w badaniu media byli menedżerowie i dyrektorzy (CEO) banków. Poziom spersonalizowanego zarzucania winy wzrósł z 7\% w 2007 roku do 23\% w 2009 roku. Spowodowało to obniżenie reputacji elit biznesowych i zmniejszenie zaufania społeczeństwa do ludzi zarządzających instytucjami finansowymi. Co ciekawe, poziom wskazywania rządów i banków centralnych za jednych z winowajców powstałego kryzysu nigdy nie przekroczył 10\%. Jim Cramer, prowadzący program Mad Money w stacji telewizyjnej CNBC, po ogłoszeniu bankructwa przez Lehman Brothers stwierdził, że odpowiednie osoby, a dokładnie bankierzy, którzy niepoprawnie założyli przebieg zjawiska, powinni zostać ukarani $^{21}$. I w tym samym tygodniu, w którym ogłoszono bankructwo przez ów bank, CNBC uzyskało najlepsze wyniki oglądalności w swojej wówczas 19-letniej historii - 502 tysiące widzów podczas dnia biznesowego. W tym czasie wskaźniki oglądalności podskoczyły również stacjom Fox, CNN oraz MSNBC. Ludzie po prostu zaczęli się bać, próbowali dowiedzieć się czegokolwiek na temat panującej sytuacji i uzyskać pomocne informacje od mediów, które wcześniej mniej chętnie ogłaszały stan kryzysowy.

\section{Podsumowanie}

Media masowe tworząc przekazy medialne, kreują również opinię publiczną, jednak związek pomiędzy relacjonowaniem zaistniałych zdarzeń a wpływaniem na ich przebieg nie jest jednoznaczny. Media w Stanach Zjednoczonych relacjonując przebieg postępującego kryzysu ekonomicznego w latach 2007-2009, były w jego opisie przede wszystkim spóźnione. Jak dowiodły przeprowadzone analizy zawartości mediów w tamtym okresie, media amerykańskie stosunkowo późno poruszyły problem kryzysowych sytuacji na rynku nieruchomości czy kredytowym.

Media dominujące na rynku nie skupiały się w dostatecznie dużym stopniu na przebiegu powyższych zjawisk. Przełom nastąpił dopiero w chwili ogłoszenia

${ }^{21}$ B. Stelter, Turning to the TV Explanations and Answers, „The New York Times”, http://www. nytimes.com/2008/09/29/business/media/29cable.html (dostęp: 21.09.2018). 
15 września 2008 roku bankructwa przez bank Lehman Brothers. Jednak nie był to temat numer jeden w środkach masowego przekazu. Informacje na temat sytuacji rynków ekonomicznych ustąpiły pierwszeństwa wieściom na temat wojny w Iraku, która zdominowała przestrzeń medialną w tamtym okresie. Był to również intensywny czas kampanii i wyborów prezydenckich.

Wnioskiem wypływającym z powyższych rozważań jest to, że media komercyjne, które są dominującą częścią rynku medialnego w USA, nie przygotowując odpowiednich przekazów mogących ostrzec odbiorców przez nadchodzącym zagrożeniem, a później także stopniując opis zaistniałej sytuacji, kierowały się głównie interesem poszczególnych organizacji.

Kwestią zastanawiającą jest, czy media amerykańskie w ten sposób realizowały swoją rolę „nocnego stróża”. Podjęły taką strategię zarządzania informacjami w przekazach medialnych na temat kryzysu i realizowały powierzoną im przez społeczeństwo misję czy jednak traktowały ją drugorzędnie, kierując się przede wszystkim aspektami czysto ekonomicznymi?

\section{Bibliografia}

Czaplicka M., Zarządzanie kryzysem w social media, Onepress, Gliwice 2014.

Lavine J.M., Wackman D.B., Managing Media Organizations: Effective Leadership of the Media, Longman, New York 1988.

Lerbinger O., The Crisis Manager: Facing Risk and Responsibility, Erlbaum, Mahwah 1997.

Nierenberg B., Publiczne przedsiębiorstwo medialne. Determinanty, systemy, modele, Wydawnictwo Uniwersytetu Jagiellońskiego, Kraków 2007.

Nierenberg B., Zarządzanie mediami. Ujęcie systemowe, Wydawnictwo Uniwersytetu Jagiellońskiego, Kraków 2011.

Picard R.G., Media Economics: Concepts and Issues, SAGE Publications, London 1989.

Pearson Ch., Clair J., Reframing Crisis Management, „Academy of Management Review” 1998, t. 23, nr 1, s. 59-76.

Roubini N., Mihm S., Ekonomia kryzysu, tłum. R. Mitoraj, Wolters Kluwer, Warszawa 2011.

Suter Ch., Herkenrath M. (red.), World Society in the Global Economic Crisis, LIT Verlag, Zurich 2012.

\section{Źródła internetowe:}

Dickinson M., Where Were the Media in the Financial Crisis of 2008, and Have We Seen This Trend Before?, http://digitalcommons.bryant.edu/cgi/viewcontent.cgi?article=1006\&con text=honors_communication (dostęp: 21.09.2018).

Stelter B., Turning to the TV Explanations and Answers, „The New York Times”, http://www.nytimes.com/2008/09/29/business/media/29cable.html (dostęp: 21.09.2018).

The Changing Narrative: How the News Media Have Covered the Slowing Economy, Pew Research Center, http://www.journalism.org/files/legacy/Economy\%20report.pdf (dostęp: 21.09.2018).

Zaleska M., Przyczyny i skutki kryzysu w USA, http://www.bankier.pl/wiadomosc/Przyczynyi-skutki-kryzysu-w-USA-1739652.html (dostęp: 21.09.2018). 